\title{
Good Corporate Governance dan Kinerja Keuangan Perusahaan Perbankan di Bursa Efek Indonesia
}

\author{
Putu Kevin Yudhia ${ }^{1}$ \\ Fakultas Ekonomi dan Bisnis \\ Universitas Udayana, Indonesia
}

\author{
A.A.G.P Widanaputra ${ }^{2}$ \\ Fakultas Ekonomi dan Bisnis \\ Universitas Udayana, Indonesia
}

\begin{abstract}
Surel : kevinyudhia@gmail.com
\section{ABSTRAK}

Kinerja keuangan adalah suatu prestasi di dalam perusahaan yang mencerminkan gambaran mengenai kondisi keuangan perusahaan tersebut. Good Corporate Governance mengatur hubungan antara pemilik saham, direksi dan komisaris. Tujuan dari penelitian ini adalah untuk mengetahui pengaruh Good Corporate Governance pada kinerja keuangan perbankan. Penelitian ini dilakukan di perusahaan perbankan yang terdaftar Bursa Efek Indonesia pada periode 2015-2017. Jumlah sampel yang diambil sebanyak 48 perusahaan perbankan, dengan metode purposive sampling. Teknik analisis data yang digunakan adalah uji asumsi klasik dan uji regresi linier berganda. Hasil penelitian ini menunjukan bahwa dewan komisaris berpengaruh negatif dan signifikan terhadap kinerja keuangan. Hasil penelitian ini menunjukan bahwa kepemilikan manajerial berpengaruh positif dan signifikan terhadap kinerja keuangan.

Kata Kunci: Good Corporate Governance; Kinerja Keuangan; Return On Assets (ROA).
\end{abstract}

\section{Good Corporate Governance and Financial Performance of Banking Companies on the Indonesia Stock Exchange}

\footnotetext{
ABSTRACT

Financial performance is an achievement in a company that reflects a picture of the company's financial condition. Good Corporate Governance regulates the relationship between shareholders, directors and commissioners. The purpose of this study was to determine the effect of Good Corporate Governance on banking financial performance. This research was conducted in banking companies listed on the Indonesia Stock Exchange in the 2015-2017 period. The number of samples taken was 48 banking companies, with a purposive sampling method. The data analysis technique used is the classical assumption test and multiple linear regression test. The results of this study indicate that the board of commissioners has a negative and significant effect on financial performance. The results of this study indicate that managerial ownership has a positive and significant effect on financial performance.

Keywords: Good Corporate Governance, Financial Performance, Return On Assets (ROA).
}

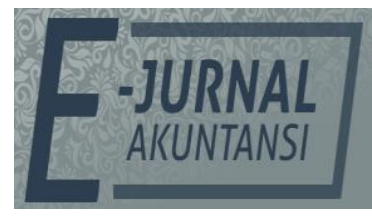

e-ISSN 2302-8556

Vol. 31 No. 3

Denpasar, Maret 2021

Hal. 524-539

DOI:

10.24843/EJA.2021.v31.i03.p01

PENGUTIPAN:

Yudhia, P.K., \&

Widanaputra, A.A.G.P.

(2021). Good Corporate Governance dan Kinerja

Keuangan Perusahaan Perbankan di Bursa Efek Indonesia. E-Jurnal Akuntansi, 31(3), 524-539

RIWAYAT ARTIKEL: Artikel Masuk: 26 Maret 2019 Artikel Diterima: 1 April 2019

Artikel dapat diakses : https://ojs.unud.ac.id/index.php/Akuntansi/index 


\section{PENDAHULUAN}

Fenomena yang biasanya terjadi di dalam good corporate governance adalah kurangnya implementasi yang juga mempengaruhi kinerja perbankan karena kurang transparannya pelaporan keuangan, adanya manajemen laba dan pemilik saham mayoritas yang cenderung dominan dalam pengambilan keputusan atas mayoritas.

Menurut M. Hanif (2014) kinerja keuangan adalah salah satu faktor yang menunjukan efektivitas dan efisien dalam organisasi untuk mencapa tujuan. Menurut Rastiana Dewi (2017) kinerja keuangan perusahaan adalah suatu hal penting yang harus dicapai karena merupakan gambaran bagi perusahaan dalam mengelola aset dan sumber dayanya. Fahmi, (2011) menyatakan bahwa kinerja keuangan adalah suatu analisis yang dilakukan untuk melihat sejauh mana perusahaan tersebut melaksanakan dengan menggunakan aturan pelaksanaan keuangan secara baik dan benar. Kinerja perusahaan merupakan suatu gambaran mengenai kondisi keuangan suatu perusahaan yang dianalisis dengan alat analisis keuangan, sehingga dapat diketahui baik maupun buruknya keadaan keuangan suatu perusahaan yang mencerminkan prestasi kerja dalam suatu periode tertentu. Hal ini penting agar sumber daya yang ada dapat digunakan secara optimal didalam menghadapi perubahan lingkungan.

Pengukuran kinerja keuangan dilakukan untuk mengetahui apakah hasil yang dicapai telah sesuai dengan perencanaan dan mencerminkan prestasi kerja dalam periode tertentu yang digambarkan dengan baik buruknya keadaan keuangan suatu perusahaan. Penilaian atas kinerja keuangan dapat diukur dengan menggunakan laporan keuangan perusahaan yang dijadikan dasar dalam pengambilan keputusan. Laporan keuangan dapat bermanfaat bagi investor, kreditur, calon investor dan para pemegang saham dalam menentukan suatu prospek mengenai perusahaan tersebut di masa depan. Sehingga menjadi penting bagi perusahaan untuk mempertahankan kinerja keuangannya.

Salah satu komponen yang terdapat dalam laporan keuangan adalah rasio profitabilitas. Rasio profitabilitas merupakan suatu informasi mengenai tingkat keuntungan yang dicapai dan efektifitas operasional suatu perusahaan. Apabila rasio ini tinggi, maka investor akan tertarik untuk menanamkan modalnya, sehingga modal tersebut dapat meningkatkan operasional yang akan berpengaruh terhadap kinerja perusahaan tersebut secara keseluruhan. Return on assets atau ROA merupakan suatu rasio yang digunakan untuk mengukur kemampuan manajemen yang dimiliki oleh bank dalam memperoleh laba. ROA juga mencerminkan laba yang dapat diperoleh suatu perusahaan dengan menggunakan asetnya. ROA juga merupakan rasio yang menjadi sebuah pertimbangan bagi investor dalam melakukan investasi. ROA juga menggambarkan laba bersih yang diperoleh suatu perusahaan melalui nilai aktiva. Dengan rasio ROA investor dapat menilai perusahaan tersebut apakah sudah efisien dalam hal penggunaan aktiva untuk operasional sehingga menghasilkan laba atau keuntungan. Pada penelitian sebelumnya, digambarkan bahwa dari tahun ke tahun terjadi penurunan kinerja keuangan yang dilihat dari ROA sebagai rasio yang digunakan untuk mengukur profitabilitas suatu perbankan. Nilai ROA yang tinggi sangat baik untuk perbankan karena 
menunjukan bahwa perbankan menghasilkan keuntungan yang besar dengan pemasukan yang kecil (Inam, 2014).

Menurut UU RI No 10 Tahun 1998 tanggal 10 November 1998 kegiatan usaha bank adalah sebagai lembaga intermediasi keuangan atau lembaga perantara keuangan dengan kegiatan utamanya menghimpun dana dari masyarakat dalam bentuk simpanan dan menyalurkannya kembali kepada masyarakat dalam bentuk kredit atau bentuk-bentuk lainnya dalam rangka meningkatkan taraf hidup rakyat banyak. Bisnis perbankan memiliki suatu tujuan yang antara lain untuk memperoleh keuntungan yang optimal dengan memberikan sebuah pelayanan salah satunya berupa jasa keuangan bagi masyarakat umum.

Teori keagenan merupakan teori yang menjelaskan hubungan agen (manajemen) dan prinsipal (para pemegang saham). Teori keagenan awalnya berhubungan dengan masalah kepemilikan melalui pembelian saham (Jensen dan Meckling, 1976:2). Teori keagenan muncul setelah adanya pemisahan kepemilikan perusahaan dengan pengelolaan di perusahaan-perusahaan yang besar. Jensen \& Meckling (1976:5) menjelaskan hubungan keagenan merupakan suatu kontrak antara manajemen (agen) dan para pemegang saham (prinsipal) yang terjadi ketika adanya satu orang atau lebih (prinsipal) mempekerjakan orang lain (agen) untuk mendelegasikan wewenang pengambilan suatu keputusan kepada agen tersebut dan agen akan memberikan jasanya kepada prinsipal.

Suatu perusahaan di dalam aktivitasnya diwakili oleh agen (manajer) yang ditunjuk oleh prinsipal (para pemegang saham). Teori agensi menyatakan bahwa agen harus bertindak rasional untuk kepentingan prinsipal. Agen di dalam prakteknya harus menggunakan keahlian, itikad baik, kebijaksanaan, dan tingkah laku yang adil dan wajar di dalam memimpin suatu perusahaan. Dalam prakteknya timbul masalah atau agency problem karena adanya suatu kesenjangan kepentingan antara manajemen (agen) dan pemegang saham (prinsipal). Agen memiliki kepentingan jangka pendek yaitu perolehan suatu insentif atas pengelolaan dana, sedangkan prinsipal memiliki kepentingan jangka panjang yaitu dana yang diinvestasikan mendapat return yang tinggi. Konflik kepentingan seperti ini yang dapat menimbulkan biaya (cost) yang muncul akibat dari adanya ketidaksempurnaan dalam penyusunan suatu kontrak antara agen dan prinsipal disebabkan oleh adanya informasi yang asimetri (Surya \& Yustiavandana, 2006:2-3).

Faktor non keuangan juga berpengaruh dalam peningkatan kinerja keuangan dan kinerja perusahaan secara keseluruhan yang juga berpengaruh terhadap nilai suatu perusahaan. Good Corporate Governance adalah salah satu faktor yang banyak dipertimbangkan oleh investor dalam menilai perusahaan. Oleh karena itu perusahaan selalu memastikan bahwa penerapan prinsip GCG sudah berjalan dengan baik. Manajemen bersama para pemegang saham juga berperan dalam penerapan prinsip GCG karena Good Corporate Governance diperlukan untuk mendorong terciptanya pasar yang efisien, transparan serta konsisten dengan peraturan perundang-undangan. Penerapan GCG perlu didukung oleh tiga pilar yang saling berhubungan, yaitu negara dan perangkatnya sebagai regulator, dunia usaha sebagai pelaku pasar, dan 
masyarakat sebagai pengguna produk dan jasa dunia usaha (Edi Wibowo, 2010). Penelitian mengenai hubungan good corporate governance dan kinerja perusahaan telah banyak dilakukan, baik penelitian yang menggunakan indeks penilaian corporate governance maupun struktur corporate governance. Darmawati, et al. (2005) meneliti hubungan antara corporate governance dan kinerja perusahaan.

Berdasarkan uraian latar belakang di atas, maka dapat menjadi suatu motivasi untuk dilakukan penelitian mengenai pengaruh good corporate governance terhadap kinerja keuangan dengan variabel diantaranya pengaruh Dewan Komisaris, Kepemilikan Manajerial, Ukuran Perusahaan serta pengaruhnya terhadap kinerja keuangan.

Corporate Governance dalam hal ini sebagai efektivitas dari mekanisme yang bertujuan untuk mengurangi konflik keagenan, yang menekankan kepada mekanisme yang legal mencegah terjadinya eksploitasi dan ekspriorasi terhadap para pemegang saham baik yang mayoritas maupun minoritas. Corporate Governance juga memberikan struktur yang dapat memfasilitasi penentuan sasaran dan tujuan dari suatu perusahaan serta merupakan sarana untuk menentukan teknik yang paling baik untuk mengawasi dalam hal ini teknik monitoring kinerja. Deni, Khomsiyah \& Rika, (2004) dalam (Oktapiyani, 2009). Corporate Governance juga merupakan suatu kunci dalam meningkatkan suatu efisiensi ekonomis yang terdiri dari hubungan antara manajemen, pemegang saham, dewan direksi, dewan komisaris dan para stakeholder yang ada dalam perusahaan tersebut.

Kinerja adalah suatu pencapaian dari suatu pekerjaan ataupun kegiatan yang dapat diukur dengan suatu standar yang dimiliki oleh perusahaan tersebut. Kinerja biasanya dilakukan terus-menerus yang bertujuan untuk mengukur sejauh mana perusahaan tersebut dalam pencapaian tujuan yang sudah ditetapkan. Pengukuran kinerja bisanya dilakukan untuk mengetahui dimana kesalahan agar segera diperbaiki dan juga sebagai evaluasi dalam pencapaian tujuan. Selain itu, pengukuran kinerja juga dilakukan agar perusahaan dapat terus bersaing dengan perusahaan lainnya. Dengan kata lain pengukuran kinerja merupakan tahap awal menuju pengendalian perusahaan yang efisien dan efektif.

Kinerja keuangan adalah pencapaian prestasi suatu perusahaan dalam periode yang dapat menggambarkan kondisi keuangan perusahaan dengan indicator kecukupan modal, likuiditas dan profitabilitas. Menurut IAI (2007) kinerja keuangan adalah kemampuan suatu perusahaan dalam mengelola dan mengendalikan sumber daya yang dimilikinya. Sedangkan menurut Sawir (2005:1) kinerja keuangan merupakan kondisi yang mencerminkan dimana keadaan keuangan suatu perusahaan berdasarkan sasaran, standar, dan kriteria yang ditetapkan.

Dengan kata lain kinerja keuangan merupakan faktor utama dan penting untuk menilai kinerja keuangan itu sendiri. Kinerja keuangan khususnya perbankan dapat dinilai dengan analisis laporan keuangan perbankan. Penilaian yang dilakukan meliputi aset, utang, dan likuiditas. Berdasarkan penilaian laporan tersebut dapat dihitung rasio keuangan untuk mengukur tingkat kesehatan bank. Analisis rasio keuangan dapat digunakan untuk mengetahui dan menilai kinerja keuangan perbankan. 
Menurut Komite Cadburry (1992) dalam Iraya (2015), GCG adalah prinsip yang mengarahkan dan mengendalikan perusahaan agar mencapai keseimbangan antara kekuatan serta kewenangan perusahaan dalam memberikan pertanggungjawabannya kepada para shareholders khususnya, dan stakeholders pada umumnya. Kelompok negara maju (OECD), umpamanya mendefinisikan GCG sebagai cara-cara manajemen perusahaan bertanggung jawab pada shareholder-nya. Para pengambil keputusan di perusahaan haruslah dapat dipertanggungjawabkan, dan keputusan tersebut mampu memberikan nilai tambah bagi shareholders lainnya.

Menurut Iqbal (2019) GCG adalah sebuah mekanisme untuk mencapai tujuan dan sasaran tersebut. Sedangkan menurut Din Ateia (2015), GCG merupakan konsep yang mempertimbangkan hubungan antara shareholders dan manajemen serta merupakan sebuah mekanisme dimana shareholders diyakinkan bahwa manajemen melayani kepentingan mereka.

ADB (Asian Development Bank) menjelaskan bahwa GCG mengandung empat nilai utama yaitu: Accountability, Transparency, Predictability dan Participation. Pengertian lain datang dari Finance Committee on Corporate Governance Malaysia. Menurut lembaga tersebut GCG merupakan suatu proses serta struktur yang digunakan untuk mengarahkan sekaligus mengelola bisnis dan urusan perusahaan ke arah peningkatan pertumbuhan bisnis dan akuntabilitas perusahaan.

Menurut Forum of Corporate Governance on Indonesia tentang Corporate Governance merupakan peraturan - peraturan yang mengatur mengenai hubungan antara pemegang saham, pengurus perusahaan, pihak kreditur, pemerintah, karyawan, serta para pemegang kepentingan intern dan ekstern lainnya yang berkaitan dengan hak - hak dan kewajiban mereka (Putri \& Ulupui, 2017). Menurut KNKG terdapat lima prinsip Good Corporate Governance antara lain Transparancy, Accountability, Responsibility, Independency, dan Fairness. Penerapan prinsip - prinsip GCG tersebut dalam sebuah perusahaan diharapkan dapat menghasilkan keputusan yang lebih baik (KNKG, 2006:5). Penerapan good corporate governance didalam perbankan sangat penting untuk diterapkan karena perbankan merupakan perusahaan yang tidak transparan sehingga masalah keagenan mungkin terjadi (Daniel, 2014). Apabila tata kelola dalam sebuah entitas itu baik, maka dapat dibuktikan bahwa kecenderungan tanggung jawab perusahaan yang lebih besar (Rambo, 2013). Karena good corporate governance kini semakin peduli dengan para stakeholders serta dampaknya terhadap kesejahteraan para stakeholders tersebut dan merupakan pendekatan jangka panjang untuk mendefinisikan good corporate governance yang memperhitungkan kepentingan para pemegang saham dan pemangku kepentingan lainnya Hence Talamo, 2011 dalam (Lipunga, 2014) dan dengan menerapkan tata kelola yang baik maka kredibilitas pasar meningkat sehingga risiko bisa ditekan serendah mungkin (Thanh Binh \& Minh Tan, 2014).

Menurut UU No.40 tahun 2007 tentang perseroan terbatas, dewan komisaris merupakan sebuah organ yang dimiliki oleh perusahaan yang bertugas baik secara umum maupun khusus sesuai dengan anggaran dasar serta memberikan nasihat kepada dewan direksi. Dewan komisaris bertanggungjawab kepada rapat umum pemegang saham yang berupa perwujudan dari 
akuntabilitas suatu pengawasan dalam rangka pelaksanaan prinsip good corporate governance. Menurut Dedu (2013), bertambahnya anggota dewan komisaris dapat menyebabkan masalah koordinasi, kontrol dan fleksibilitas dalam proses pengambilan keputusan. Berdasarkan hasil penelitian dari Diana (2016) dan Filip \& Vesna (2013) menyatakan bahwa dewan komisaris berpengaruh negatif dan signifikan terhadap kinerja keuangan karena apabila jumlah dewan komisaris meningkat maka kinerja keuangan akan menurun.

Peneliti dapat berasumsi bahwa dewan komisaris memiliki pengaruh terhadap kinerja keuangan perbankan. Dewan komisaris adalah salah satu dari fungsi kontrol yang terdapat dalam perusahaan. Dewan komisaris memiliki tugas yaitu melaksanakan fungsi mengawasan dari prinsipal dan mengontrol tindakan oportunis dari pihak manajemen yang dalam hal ini mewakili mekanisme internal utama. Berdasarkan uraian, maka dapat dirumuskan hipotesis sebagai berikut.

$\mathrm{H}_{1}$ : Dewan Komisaris berpengaruh negatif dan signifikan terhadap kinerja keuangan.

Menurut El-Chaarani (2014), pengukuran kepemilikan manajerial dilakukan berdasarkan persentase dari total saham yang dimiliki oleh para direktur eksekutif dibandingkan dengan total saham secara keseluruhan. Kepemilikan manajerial merupakan jumlah saham secara keseluruhan yang dimiliki oleh pihak manajemen dari seluruh modal saham yang dikelola. Berdasarkan hasil penelitian oleh MG Indarti (2013) meyatakan bahwa kepemilikan manajerial berpengaruh positif karena semakin besar proporsi kepemilikan manajerial maka dapat menyatukan kepentingan antara manajer dan kepemilikan saham. Widagdo (2014) menyatakan bahwa kepemilikan manajerial berpengaruh positif terhadap kinerja keuangan karena apabila direktur memiliki saham perusahaan tersebut maka kinerja keuangan akan berada dalam titik yang optimal. Sedangkan Claudia Aluy (2017) menyatakan bahwa kepemilikan manajerial berpengaruh signifikan terhadap kinerja keuangan.

$\mathrm{H}_{2}$ : Kepemilikan manajerial berpengaruh positif dan signifikan terhadap kinerja keuangan.

Menurut El-Chaarani (2014) dalam Melia (2015), menyatakan bahwa ukuran perusahaan merupakan suatu tolok ukur yang dimana untuk menunjukan ukuran tersebut digunakan total aset perusahaan dengan menggunakan log total asset. Ukuran perusahaan yang besar dapat menikmati operasi berskala besar yang meningkatkan profitabilitas dan mengurangi biaya operasi (Pervan \& Visic, 2012) dalam (Turen, 2018). Semakin besar ukuran perusahaan maka sumber daya yang dimiliki oleh perusahaan pun akan bertambah besar (James, 2015). Ukuran perusahaan dapat menjadi pertimbangan good corporate governance yang penting. Ukuran perusahaan yang optimal harus ditegakkan agar good corporate governance dan kinerja keuangan menjadi baik (Fanta, 2013). Berdasarkan hasil penelitian dari Naushad \& Malik (2015) menyatakan bahwa ukuran perusahaan berpengaruh positif terhadap kinerja keuangan. Johl, et al. (2015) menyatakan bahwa ukuran perusahaan berpengaruh positif terhadap kinerja keuangan. Theacini (2014) meyatakan bahwa ukuran perusahaan berpengaruh signifikan terhadap kinerja keuangan. Rastiana Dewi 
(2017) menyatakan bahwa ukuran perusahaan berpengaruh positif dan signifikan terhadap kinerja keuangan.

Peneliti berasumsi bahwa ukuran perusahaan mempengaruhi kinerja keuangan karena semakin besar ukuran perusahaan maka kemampuan finansialnya semakin besar dan hal ini cukup mempengaruhi kinerja keuangan secara keseluruhan. Semakin besar ukuran perusahaan, maka dapat dipastikan dana yang dikelola semakin besar dan kompleks. Dengan demikian perusahaan besar selalu berusaha untuk menjaga stabilitas dan kondisi dengan cara meningkatkan dan mempertahankan kinerja secara keseluruhan. Berdasarkan uraian, maka dapat dirumuskan hipotesis sebagai berikut.

$\mathrm{H}_{3}$ : Ukuran perusahaan berpengaruh positif dan signifikan terhadap kinerja keuangan.

\section{METODE PENELITIAN}

Lokasi penelitian ini terdapat di Bursa Efek Indonesia (BEI) melalui situs www.idx.co.id sumber data penelitian ini adalah laporan keuangan tahunan perusahaan perbankan yang terdaftar di BEI. Alasan peneliti memilih lokasi penelitian ini adalah karena Bursa Efek Indonesia memiliki informasi mengenai perusahaan perbankan yang telah go public dengan lengkap beserta dengan harga saham, profil perusahaan serta laporan keuangan dan posisi keuangan perusahaan tersebut.

Populasi yang digunakan dalam penelitian ini adalah seluruh perusahaan perbankan yang terdaftar di Bursa Efek Indonesia. Sampel dalam penelitian ini sebanyak 48 perusahaan perbankan yang terdaftar di Bursa Efek Indonesia. Metode penentuan sampel yang digunakan dalam penelitian ini adalah metode purposive sampling.

Menurut Hanafi \& Halim (2003:27) return on assets (ROA) adalah rasio keuangan perusahaan yang terkait dengan profitabilitas mengukur kemampuan perusahaan dalam menghasilkan keuntungan atau laba pada tingkat pendapatan, aset dan modal saham tertentu. Dengan mengetahui ROA, kita dapat menilai apakah perusahaan tersebut telah efisien ataupun tidak dalam menggunakan aktivanya untuk kegiatan operasinya dalam rangka menghasilkan keuntungan. Berikut ini adalah rumus untuk menghitung ROA.

$R O A=\frac{\text { laba bersih }}{\text { total aset }} \times 100 \%$

Penelitian ini menggunakan adalah model regresi linear berganda dengan taraf signifikansi sebesar 5\% untuk menguji pengaruh dewan komisaris, kepemilikan manajerial dan ukuran perusahaan terhadap kinerja keuangan perbankan. Data dalam penelitian ini diolah dengan bantuan program SPSS. Hasil analisis dalam penelitian ini dapat dinyatakan dalam model persamaan regresi linear berganda sebagai berikut:

$Y=\alpha+\beta_{1} X 1+\beta_{2} . X 2+\beta_{3} . X 3+$.

Keterangan:

$\mathrm{Y} \quad=$ Kinerja keuangan

a $=$ Konstanta

$\beta_{1}, \beta_{2}, \beta_{3} \quad=$ Koefisien regresi variabel independen 


$\begin{array}{ll}\mathrm{X} 1 & =\text { Dewan komisaris } \\ \mathrm{X} 2 & =\text { Kepemilikan manajerial } \\ \mathrm{X} 3 & \quad=\text { Ukuran perusahaan }\end{array}$

\section{HASIL DAN PEMBAHASAN}

Penelitian ini dilakukan pada 48 perusahan perbankan di Bursa Efek Indonesia. Data penelitian ini didapat dari pencarian mengenai laporan keuangan dan posisi keuangan yang terdapat di website resmi Bursa Efek Indonesia www.idx.co.id. Terdapat 37 perusahaan yang memenuhi syarat berdasarkan kriteria yang sudah ditetapkan yaitu sudah diaudit oleh auditor dan tersedia lengkap. Peneliti menggunakan sebanyak 113 laporan keuangan dan posisi keuangan setelah dilakukan pemilihan sampel berdasarkan kriteria yang dimana laporan keuangan harus lengkap dan sudah diaudit oleh auditor. Hal ini dikarenakan apabila laporan keuangan lengkap maka perhitungan dan pengolahan data akan lebih mudah dilakukan. Rincian mengenai pemilihan kriteria sampel ditetapkan pada Tabel 1.

Tabel 1. Proses Penentuan Sampel Penelitian

\begin{tabular}{llll}
\hline No & Keterangan & Jumlah \\
\hline 1 & $\begin{array}{l}\text { Perusahaan perbankan yang terdaftar di BEI } \\
\text { periode 2015-2017 }\end{array}$ & 48 \\
2 & $\begin{array}{l}\text { Perusahaan perbankan yang terdaftar di BEI yang } \\
\text { tidak menerbitkan laporan keuangan tahunan }\end{array}$ & \\
& secara berturut-turut dalam periode 2015-2017 \\
& $\begin{array}{l}\text { Perusahaan perbankan yang terdaftar di BEI yang } \\
\text { tidak menyajikan data yang terkait dengan variabel }\end{array}$ & $(11)$ \\
& secara lengkap dalam periode 2015-2017 & 37 \\
& Jumlah sampel & 3 \\
Tahun pengamatan & 113 \\
\hline
\end{tabular}

Sumber: Data Penelitian, 2018

Tabel 1, menunjukan bahwa dari 48 perusahaan perbankan yang terdaftar di Bursa Efek Indonesia, terdapat 37 perusahaan yang memenuhi syarat sebagai sebuah sampel karena kriteria sampel yang mengharuskan data yang ditampilkan harus lengkap dan terdapat 11 perusahaan perbankan yang tidak menampilkan laporan keuangan secara lengkap sehingga jumlah data yang digunakan sebanyak 113 data dari 37 perusahaan perbankan yang terdaftar di Bursa Efek Indonesia selama periode 2015-2017. Hasil dari uji statistik deskriptif dapat dilihat pada Tabel 2.

\section{Tabel 2. Hasil Uji Statistik Deskriptif}

\begin{tabular}{llllll}
\hline & $\mathrm{N}$ & Minimum & Maximum & Mean & $\begin{array}{l}\text { Std } \\
\text { Deviation }\end{array}$ \\
\hline ROA & 113 & $-0,04$ & 0,05 & 0.0137 & 0,01741 \\
DK & 113 & 0 & 9 & 4,6991 & 1,83169 \\
KM & 113 & 0 & 0,7 & 0,1398 & 0,01812 \\
SIZE & 113 & 28.05 & 35.20 & 31,6707 & 1,66647 \\
\hline
\end{tabular}

Sumber: Data Penelitian, 2018 
Nilai rata-rata Return on assets (ROA) sebesar 0,0137 yang berarti bahwa perusahaan perbankan menghasilkan laba bersih sebesar 0,0137 dengan standar deviasi 0,017. Nilai minimum sebesar -0,04 terdapat pada Bank Pembangunan Daerah Banten dan nilai maksimum sebesar 0,05 terdapat pada Bank BNI.

Nilai rata-rata Dewan Komisaris sebesar 4,6991 yang berarti bahwa jumlah dewan komisaris sebesar 4,6991 dengan standar deviasi sebesar 1,83. Nilai minimum sebanyak 0 orang terdapat pada Bank Pembangunan Daerah Sulawesi Utara dan nilai maksimum sebanyak 9 orang terdapat pada Bank BRI dan CIMB Niaga.

Nilai rata-rata Kepemilikan Manajerial sebesar 0,1398 yang berarti bahwa jumlah kepemilikan manajerial sebesar 0,1398 dengan standar deviasi sebesar 0,018. Nilai minimum sebesar 0 terdapat pada Bank MNC Internasional dan nilai maksimum sebesar 0,7 terdapat pada Bank BPD Nusa Tenggara Timur.

Nilai rata-rata Ukuran Perusahaan sebesar 31,6707 yang berarti bahwa ukuran perusahaan sebesar 31,6707 dengan standar deviasi sebesar 1,66. Nilai minimum sebesar 28,05 terdapat pada Bank Artos dan nilai maksimum sebesar 35,20 terdapat pada Bank BRI.

Uji normalitas dalam penelitian ini menggunakan uji K-S atau uji Kolomogorov-Smirnov menggunakan program SPSS. Jika hasil signifikansi nilai residual sebesar $>0,05$ berarti residual telah terdistribusi secara normal. Hasil dari uji normalitas dapat dilihat pada Tabel 3.

Tabel 3. Hasil Uji Normalitas

\begin{tabular}{lll}
\hline & & $\begin{array}{l}\text { Unstandardized } \\
\text { Residual }\end{array}$ \\
\hline $\mathrm{N}$ & & 113 \\
Normal Parameters, $b$ & Mean & 0,001 \\
& Std. Deviation & 1,004 \\
Most Extreme Differences & Absolute & 0,083 \\
& Positive & 0,083 \\
& Negative & $-0,062$ \\
Test Statistics & & 0,083 \\
Asymp. Sig. (2-tailed) & & 0,051 \\
\hline
\end{tabular}

Sumber: Data Penelitian, 2018

Berdasarkan Tabel 3, taraf signifikansi dari persamaan regresi moderasi adalah sebesar 0,051 dengan taraf signifikansi > 0,05 menunjukan bahwa data dalam penelitian ini terdistribusi secara normal.

Uji heterokedastisitas dalam penelitian ini menggunakan uji Glejser yang dilakukan dengan cara meregresikan variabel bebas terhadap absolut residual. Jika tingkat signifikansi variabel bebas sebesar > 0,05 maka disimpulkan bahwa tidak terjadi heterokedastisitas. Hasil dari uji heterokedastisitas disajikan dalam Tabel 4.

Tabel 4. Hasil Uji Heterokedastisitas

\begin{tabular}{ll}
\hline Variabel & Sig. \\
\hline DK & 0,131 \\
KM & 0,593 \\
SIZE & 0,537 \\
\hline
\end{tabular}

Sumber: Data Penelitian, 2018 
Berdasarkan Tabel 4, maka dapat disimpulkan bahwa data tersebut telah terbebas dari heterokedastisitas. Hal itu ditunjukan dengan nilai variabel bebas secara keseluruhan berada pada tingkat signifikansi sebesar $>0,05$.

Untuk mendeteksi ada tidaknya autokorelasi maka dalam penelitian ini digunakan uji Durbin-Watson atau $D-W$ test dengan ketentuan $\mathrm{du}<\mathrm{dw}<(4-\mathrm{du})$. Hasil dari uji autokorelasi disajikan dalam Tabel 5, sebagai berikut.

Tabel 5. Hasil Uji Autokorelasi

\begin{tabular}{ll}
\hline DW (Durbin-Watson) & Keterangan \\
\hline 1,91 & $\mathrm{du}<\mathrm{dw}<(4-\mathrm{du})$ \\
\hline Sumber: Data Penelitian, 2018 &
\end{tabular}

Berdasarkan Tabel 5, hasil uji autokorelasi menunjukan nilai dari DW sebesar 1,91. Hasil telah dibandingkan dengan nilai tabel DW yang menggunakan nilai signifikansi 5\%, jumlah sampel sebanyak 113, dan jumlah variabel independent sebanyak $3(\mathrm{k}=3)$ diperoleh nilai $\mathrm{dL}=1,65735$ dan $\mathrm{dU}=$ 1,72931. Oleh karena $\mathrm{du}<\mathrm{dw}<4-\mathrm{du}$ yaitu sejumlah $1,65<1,91<2,27$ maka dapat disimpulkan bahwa dalam penelitian ini tidak terjadi autokorelasi.

Tabel 6. Hasil Uji Regresi Berganda

\begin{tabular}{|c|c|c|c|c|c|c|c|}
\hline \multirow[b]{2}{*}{ Variabel } & \multirow[b]{2}{*}{ Konstanta } & \multirow[b]{2}{*}{ Koefisien Regresi } & \multicolumn{2}{|c|}{ Nilai $R$} & \multirow{2}{*}{$\begin{array}{l}\text { Nilai F } \\
\text { F Hitung } \\
\end{array}$} & \multirow[t]{2}{*}{$\mathrm{t}$} & \multirow[t]{2}{*}{ sig } \\
\hline & & & $\mathrm{R}^{2}$ & Adj $R^{2}$ & & & \\
\hline SIZE & & 0,008 & & & & 5,641 & 0,000 \\
\hline DK & $-0,213$ & $-0,006$ & 0,253 & 0,233 & 12,331 & $\overline{-} 4,739$ & 0,000 \\
\hline KM & & 0,015 & & & & 1,998 & 0,048 \\
\hline
\end{tabular}

Sumber: Data Penelitian, 2018

Berdasarkan nilai konstanta dan nilai koefisien regresi pada Tabel 6, maka dapat disusun persamaan regresi sebagai berikut.

$$
\mathrm{ROA}=-0,213-0,006 \mathrm{DK}+0,015 \mathrm{KM}+0,008 \mathrm{SIZE}
$$

Berdasarkan persamaan regresi tersebut dapat diketahui, bahwa nilai konstanta sebesar - 0,213 berarti apabila seluruh variabel independent konstan maka nilai ROA atau kinerja keuangan sebesar -0,213. Dilihat dari nilai Adjusted $R^{2}$ sebesar 0,233 . Hal ini menunjukan bahwa kinerja keuangan perbankan yang terdaftar di BEI selama periode 2015-2017 dipengaruhi oleh 23,3\% variabel dewan komisaris, kepemilikan manajerial dan ukuran perusahaan, sedangkan sisa $76,7 \%$ dipengaruhi oleh variabel lain diluar model. Dapat diketahui bahwa nilai $\mathrm{F}$ sebesar 12,331 dengan signifikansi sebesar 0,000 dan lebih rendah dari level signifikansi sebesar 0,05 yang berarti model analisis regresi linear berganda tersebut layak digunakan.

Berdasarkan uji hipotesis tersebut dapat diketahui bahwa nilai $\mathrm{t}$ dari dewan komisaris memiliki nilai sebesar $-4,739$ dan nilai sig sebesar 0,000 hal ini menunjukan bahwa nilai tersebut lebih rendah dari $a=0,05$ yang berarti $\mathrm{H}_{1}$ diterima yang dimana Hipotesis 1 menyatakan bahwa Dewan Komisaris berpengaruh negatif dan signifikan terhadap kinerja keuangan, sehingga dapat disimpulkan bahwa semakin tinggi jumlah dewan komisaris yang ada dalam suatu perusahaan perbankan berarti semakin rendah kinerja keuangan. Hal ini berarti ketika jumlah dewan komisaris bertambah maka kinerja keuangan akan menurun karena dewan komisaris hanya sebagai fomalitas dalam rangka pemenuhan regulasi. 
Berdasarkan uji hipotesis dapat diketahui bahwa nilai $\mathrm{t}$ dari kepemilikan manajerial memiliki nilai sebesar 1,998 dan nilai sig sebesar 0,048 hal ini menunjukan bahwa nilai tersebut lebih rendah dari $a=0,05$ yang berarti $\mathrm{H}_{2}$ diterima yang dimana hipotesis 2 menyatakan bahwa kepemilikan manajerial berpengaruh positif terhadap kinerja keuangan, sehingga dapat disimpulkan bahwa semakin tinggi kepemilikan manajerial dalam suatu perusahaan perbankan maka kinerja keuangan semakin meningkat. Hal ini berarti apabila kepemilikan manajerial dalam suatu perusahaan meningkat maka kinerja keuangan akan meningkat karena pihak manajemen yang juga sebagai investor akan cenderung berusaha meningkatkan kinerja keuangan karena apabila kinerja keuangan baik maka harga saham pun akan meningkat.

Berdasarkan uji hipotesis dapat diketahui bahwa nilai $\mathrm{t}$ dari ukuran perusahaan memiliki nilai sebesar 5,641 dan nilai sig sebesar 0,000 hal ini menunjukan bahwa nilai tersebut lebih rendah dari $a=0,05$ yang berarti $\mathrm{H}_{3}$ diterima yang dimana hipotesis 3 menyatakan bahwa ukuran perusahaan berpengaruh positif dan signifikan terhadap kinerja keuangan, sehingga dapat disimpulkan bahwa semakin besar ukuran perusahaan maka kinerja keuangan akan meningkat. Hal ini berarti apabila ukuran perusahaan meningkat maka kinerja keuangan akan meningkat yang tercermin dari besar total aset yang dimiliki seperti jumlah kantor cabang dan kemampuan finansial dari perusahaan perbankan itu sendiri.

Tabel 7. Koefisien determinasi

\begin{tabular}{llllll}
\hline Model & $\mathrm{R}$ & $\mathrm{R}$ Square & Adjusted $\mathrm{R}$ Square & $\begin{array}{l}\text { Std. Error of the } \\
\text { Estimate }\end{array}$ \\
\hline 1 & 0,503 & 0,253 & 0,233 & 0,01525 \\
\hline
\end{tabular}

Sumber: Data Penelitian, 2018

Koefisien determinasi atau $\mathrm{R}^{2}$ digunakan untuk mengetahui adanya persentase pengaruh dari variabel independen pada perubahan variabel dependen. Koefisien determinasi pada model regresi dapat diketahui dengan nilai R2. Pada Tabel 7, nilai Adjusted $R$ square sebesar 0,233 atau 23,3 persen. Hal ini berarti bahwa variabel kinerja keuangan yang diproksikan dengan ROA dapat dijelaskan dengan variabel DK, KM dan SIZE sebesar 23,3 persen dan sisa 76,7 persen dipengaruhi oleh variabel lain.

Tabel 8. Uji kelayakan model (uji F)

\begin{tabular}{lllllll}
\hline & Model & Sum of Squares & $\mathrm{df}$ & Mean Square & $\mathrm{F}$ & Sig. \\
\hline 1 & Regression & 0,009 & 3 & 0,003 & 12,331 & 0,000 \\
& Residual & 0,025 & 109 & 0,000 & & \\
& Total & 0,034 & 112 & & & \\
\hline
\end{tabular}

Sumber: Data Penelitian, 2018

Uji kelayakan model atau uji $\mathrm{F}$ digunakan untuk mengetahui apakah model regresi dalam penelitian ini layak digunakan ataupun tidak. Pada Tabel 8, nilai $F$ hitung sebesar 12,331 dengan signifikansi 0,000. Nilai signifikansi tersebut lebih rendah dari level signifikansi sebesar 0,05 yang berarti bahwa model analisis regresi linear berganda layak digunakan.

Dewan komisaris berpengaruh negatif dan signifikan terhadap kinerja keuangan yang berarti bahwa jumlah dewan komisaris yang ada didalam perusahaan dapat memberikan pengaruh terhadap kinerja keuangan. Bank yang 
memiliki jumlah anggota dewan komisaris yang banyak dinilai dapat memberikan pengaruh signifikan terhadap kinerja keuangan di perbankan itu sendiri. Semakin banyak anggota dewan komisaris maka kinerja keuangan perusahaan menurun.

Menurut Filip \& Vesna (2013) semakin banyak jumlah dewan komisaris, maka kinerja keuangan akan menurun. Hasil penelitian ini sesuai dengan penelitian yang dilakukan Diana (2016) dan Filip \& Vesna (2013) yang menyatakan bahwa dewan komisaris berpengaruh negatif dan signifikan terhadap kinerja keuangan.

Kepemilikan manajerial berpengaruh positif dan signifikan terhadap kinerja keuangan berarti bahwa banyak atau sedikitnya kepemilikan manajerial didalam perusahaan memberikan pengaruh signifikan terhadap kinerja suatu perusahaan. Kepemilikan manajerial yang besar juga memiliki risiko yang besar pula, sehingga pihak manajemen memiliki jabatan yang rangkap yaitu sebagai pihak manajemen pengelola perusahaan dan juga sebagai pemilik saham atau investor.

Hasil penelitian ini sesuai dengan penelitian yang dilakukan oleh Widagdo (2014) yang menyatakan bahwa kepemilikan manajerial berpengaruh positif terhadap kinerja keuangan. MG Indarti (2013) yang menyatakan bahwa kepemilikan manajerial berpengaruh positif signifikan terhadap kinerja keuangan dan Claudia Aluy (2017) yang menyatakan bahwa kepemilikan manajerial bepengaruh signifikan terhadap kinerja keuangan.

Ukuran perusahaan berpengaruh positif dan signifikan terhadap kinerja keuangan berarti bahwa semakin besar ataupun kecil ukuran perusahaan tersebut maka kinerja keuangan dapat berpengaruh secara signifikan. Perusahaan yang memiliki aset besar juga memiliki biaya yang besar sehingga ukuran perusahaan memiliki pengaruh optimal terhadap kinerja keuangan. Hasil penelitian ini sesuai dengan yang dilakukan oleh Rastiana Dewi (2017) yang menyatakan bahwa ukuran perusahaan berpengaruh positif dan signifikan terhadap kinerja keuangan. Theacini (2014) menyatakan bahwa ukuran perusahaan berpengaruh signifikan terhadap kinerja keuangan. Naushad \& Malik (2015) dan Johl, et al. (2015) yang menyatakan bahwa ukuran perusahaan berpengaruh positif terhadap kinerja keuangan.

Penelitian ini dilakukan agar dapat memberikan dukungan empiris terhadap teori mengenai pengaruh dewan komisaris, kepemilikan manajerial dan ukuran perusahaan terhadap kinerja keuangan. Berdasarkan hasil uji dalam penelitian ini dapat dinyatakan bahwa kinerja keuangan perbankan dipengaruhi oleh dewan komisaris, kepemilikan manajerial dan ukuran perusahaan.

Berdasarkan hasil penelitian ini maka perlu diperhatikan bahwa dalam meningkatkan kinerja keuangan perbankan, pihak manajemen perbankan harus juga mempertimbangkan jumlah anggota dewan komisaris, dan besarnya kepemilikan institusional karena semakin banyak anggota dewan komisaris maka pembagian tugas dan wewenang akan optimal. Semakin besar kepemilikan manajerial maka pihak manajemen dapat berperan sebagai investor sekaligus operasional. 


\section{SIMPULAN}

Hasil penelitian ini menunjukan bahwa dewan komisaris berpengaruh negatif dan signifikan terhadap kinerja keuangan. Hal ini berarti semakin tinggi jumlah dewan komisaris yang dimiliki oleh suatu perusahaan maka kinerja keuangan suatu perusahaan semakin menurun. Jumlah dewan komisaris yang tinggi tidak dapat meningkatkan kinerja keuangan karena keberadaannya hanya formalitas dalam rangka memenuhi regulasi dan apabila jumlah dewan komisaris tinggi maka dalam pembagian tugas terjadi tumpang tindih dalam menjalankan tugasnya. Hal ini juga mempengaruhi kinerja keuangan secara keseluruhan.

Hasil penelitian ini menunjukan bahwa kepemilikan manajerial berpengaruh positif dan signifikan terhadap kinerja keuangan. Hal ini berarti semakin tinggi jumlah kepemilikan manajerial yang terdapat dalam suatu perusahaan maka kinerja keuangan akan semakin meningkat. Jumlah kepemilikan manajerial yang tinggi dapat meningkatkan kinerja keuangan karena pihak manajemen yang juga merangkap sebagai investor akan termotivasi untuk selalu meningkatkan kinerja keuangan karena hal ini dapat mempengaruhi nilai perusahaan dan harga saham sehingga kinerja keuangan suatu perusahaan perbankan akan menjadi lebih optimal.

Hasil penelitian ini menunjukan bahwa ukuran perusahaan berpengaruh positif dan signifikan terhadap kinerja keuangan. Hal ini berarti semakin besar ukuran perusahaan tersebut maka kinerja keuangan akan meningkat. Ukuran perusahaan yang besar mencerminkan kekuatan finansial yang dimiliki oleh suatu perusahaan perbankan tersebut. Ukuran perusahaan yang besar juga mencerminkan total aset yang dimiliki dimana semakin besar total aset perusahaan maka akan semakin mendapat perhatian di masyarakat. Besarnya total aset yang dimiliki ditandai dengan banyaknya dividen yang diberikan kepada pemilik saham, banyaknya kaontor cabang yang dimiliki beserta persebarannya. Hal ini secara otomatis menciptakan citra dan reputasi perusahaan tersebut di mata masyarakat yang mempengaruhi nilai perusahaan dan harga saham perusahaan tersebut. Dengan begitu, perusahaan akan selalu termotivasi untuk selalu meningkatkan kinerja keuangannya dan mempertahankannya.

Bagi perusahaan perbankan sebaiknya perlu menjaga kinerja keuangan agar tetap sesuai dengan peraturan Otoritas Jasa Keuangan atau OJK. Perbankan harus mampu menekan kerugian agar tidak mempengaruhi kinerja keuangan secara keseluruhan. Karena apabila perusahaan perbankan merugi maka kinerja keuangan akan menurun, namun apabila perusahaan perbankan mampu mencetak keuntungan maka kinerja keuangan akan meningkat. Hal ini diperlukan agar kestabilan kinerja keuangan perbankan dapat terjaga.

Sampel yang digunakan dalam penelitian ini terbatas hanya perusahaan perbankan yang terdaftar di Bursa Efek Indonesia, sehingga penelitian selanjutnya dapat melakukan penelitian terhadap perusahaan perbankan baik yang terdaftar di Bursa Efek Indonesia maupun yang tidak terdaftar di Bursa Efek Indonesia atau dengan Lembaga lain seperti Bank Perkreditan Rakyat dan Lembaga Perkreditan Desa ataupun dengan perusahan jenis lainnya seperti manufaktur maupun pertambangan. Selain itu peneliti selanjutnya dapat mempertimbangkan faktor lain seperti nilai perusahaan dan harga saham. 
Peneliti selanjutnya juga dapat menambah variabel lain seperti dewan direksi, komite audit dan kepemilikan institusional. Penelitian ini menggunakan satu proksi dari penerapan good corporate governance yaitu dewan komisaris. Struktur kepemilikan menggunakan satu proksi yaitu kepemilikan manajerial. Peneliti selanjutnya juga dapat menambah proksi selain menambah jumlah variabel seperti ROE (Return on Equity) dan CAMEL. Peneliti selanjutnya juga dapat menambah periode penelitian untuk memperbaharui penelitian yang sejenis.

\section{REFERENSI}

Aktan, B., Turen, S., Tvaronavičienė, M., Celik, S., \& Alsadeh, H. A. (2018). Corporate Governance And Performance Of The Financial Firms In Bahrain, Polish Journal of Management Studies Vol. 17(1), 39-58.

Adestian, Yuda (2013). Pengaruh Dewan Komisaris, Dewan Direksi, Dewan Komisaris Independen, Komite Audit dan Ukuran Perusahaan Pada Kinerja Perusahaan Perbankan Yang Listing di BEI Pada Tahun 2012-2014. Jurnal Fakultas Ekonomi dan Bisnis Universitas Dian Nuswantoro

Agustina, M., Jogi, Y., \& Si, M. (2014). Pengaruh Good Corporate Governance terhadap Kinerja Perusahaan pada Sektor Keuangan, Business Accounting Review Vol. 3, No. 1, Hal: 223-232

Al-Baidhani, D. A. (2013). The Effects of Corporate Governance on Bank Performance: Evidence from the Arabian Peninsula. SSRN. Putra Business School

Aluy, C.A. dan J.E. Tulung (2017). Pengaruh Keberadaan Wanita dalam Manajemen Puncak dan Kepemilikan Manajerial Terhadap Kinerja Keuangan Perbankan (Studi Pada Bank BUMN dan Bank Swasta Nasional Devisa di Indonesia). Jurnal EMBA, Vol.5, No.2, Hal. 821-828.

Chaarani, E. (2014). The impact of corporate governance on the performance of Lebanese banks. The International Journal of Business and Finance Research, Vol. 8, No. 5, 3Hal. 5-46.

Cheng, Q \& Warfield, TD. (2005), 'Equity incentives and earnings management', The Accounting Review, Vol.80, No.2, Hal: 441-476.

Chrisdiato, B. (2013). "Peran Komite Audit dalam Good Corporate Governance". Jurnal Akuntansi Aktual Universitas Surabaya.

Dao, B., \& T. Dao. (2014). Corporate Governance and Bank Performance - An International Comparison: Vietnam and Malaysia. SSRN.

Dedu, V., dan G. Chitan. (2013). The Influence of Internal Corporate Governance on Bank Performance - An Empirical Analysis for Romania. Procedia Social and Behavioral Sciences.

Dewi, P.E.R dan A. Indra Tenaya (2017). Pengaruh Penerapan GCG dan Ukuran Perusahaan Terhadap Kinerja Keuangan Perbankan di BEI Periode 20132016. E-Jurnal Akuntansi Universitas Udayana, Vol. 21, No. 1, Hal: 310-329.

Elisetiawati, E. dan B. Artinah. (2016). Pengaruh Pelaksanaan Good Corporate Governance, Kepemilikan Institusional dan Leverage Terhadap Kinerja Keuangan (Studi Pada Industri Perbankan di Bursa Efek Indonesia). Jurnal Manajemen dan Akuntansi, Vol. 17, No. 1, Hal: 17-28

Fanta, A. B. (2013). Corporate Governance and impact on Bank Performance. Journal of Finance and Accounting, Vol. 1, No. 1. 
Fidanoski, F., Mateska, V., \& Simeonovski, K. (2013). Corporate Governance and Bank Performance: Evidence from Macedonia. Munich Personal RePEc Archive.

Hanif, M. (2014). Pengaruh Penerapan Corporate Governance Terhadap Laba Perusahaan. Fakultas Ekonomi dan Bisnis Universitas Muhammadiyah Surakarta.

Hartono, D. dan Y. Nugrahanti. (2014). Pengaruh Mekanisme Corporate Governance terhadap kinerja keuangan perusahaan perbankan. Dinamika Akuntansi, Keuangan dan Perbankan, Vol. 3, No. 2, Hal: 191-205

Inam, H. dan A. Mukhtar. (2014). Corporate governance and its impact on performance of banking sector in Pakistan. International Journal of Information, Business and Management, Vol. 6, No.3.

Indarti, M.G.K. dan L. Extaliyus (2013). Pengaruh Corporate Governance Perception Index (CGPI), Struktur Kepemilikan, dan Ukuran Perusahaan Terhadap Kinerja Keuangan. Jurnal Bisnis dan Ekonomi (JBE), Vol. 20, No.2, Hal: 171-183

Iqbal, S., Nawaz, A., \& Ehsan, S. (2019). Journal of Asian Economics Financial performance and corporate governance in micro finance: Evidence from Asia. Journal of Asian Economics, Vol. 60, 1-13.

Iraya, C., Mwangi, M., \& Muchoki, G. (2015). The effect of corporate governance practices on earningd management of company listed at the Nairobi securities exchange. European Scientific Journal, Vol.11, No.1.

James, B. J., dan Joseph, C. (2015). Corporate Governance Mechanisms and Bank Performance: Resource-based View. Procedia Economics and Finance.

Jensen, M.C dan Meckling, W.H. (1976). The Theory of the Firm: Managerial Agency Cost and Ownership Structures. Journal of Financial Economics. Vol.3, pp. 305-360.

Johl, S. K., Kaur, S., \& Cooper, B. J. (2015). Board Characteristics and Firm Performance: Evidence from Malaysian Public Listed Firms. Journal of Economics, Business and Management, Vol. 3, No. 2.

Lipunga, A. M. (2014). Corporate Governance Practices in Commercial Banking Sector of Malawi: Evidence from Annual Reports. Journal of Applied Finance and Banking. Vol. 4, No. 5, 2014.

Machmud dan Djakman. (2008), Pengaruh Struktur Kepemilikan terhadap Luas Pengungkapan Tanggung Jawab Sosial (CSR Disclosure) pada Laporan Tahunan Perusahaan: Study Empiris pada Perusahaan Publik yang Tercatat di Bursa Efek Indonesia 2006. Simposium Nasional Akuntansi 11.

Naushad, M., dan M.A. Malik. (2015). Corporate governance and bank performance: A study of selected banks in GCC region. Asian Social Science, Vol. 11, No. 9.

Pakpahan, N.T. dan Rasyid, E. (2017). Pengaruh Good Corporate Governance Terhadap Kinerja Keuangan (Studi kasus pada perusahaan perbankan yang terdaftar di Bursa Efek Indonesia Tahun 2012-2015). Fundamental management journal online, Vol. 2, No. 1, Hal: 5-13

Putri, D.S.K. (2016). Pengaruh Penerapan Good Corporate Governance Terhadap Kinerja Keuangan (Studi Empiris Pada Perusahaan Perbankan yang 
Terdaftar Di BEI Tahun 2010-2014). Fakultas Ekonomi dan Bisnis Universitas Muhammadiyah Surakarta.

Rambo, C. M. (2013). “Influence of The Capital Markets Authority's Corporate Governance Guidelines on Financial Performance of Commercial Banks In Kenya" Charles. The International Journal of Business and Finance Research, 7(3), 77-92, Vol. 7, No. 3, 2013.

Rompas, S.A.C. dan Sri Murni (2018). Pengaruh Pengungkapan Corporate Governance dan Ukuran Perusahaan Terhadap Kinerja Keuangan Perbankan Yang Terdaftar di Bursa Efek Indonesia Periode 2012-2016. Jurnal EMBA Vol.6 No.3, Hal. 1508 - 1517

Surya, Indra \& Ivan Yustiavandana. (2006). Penerapan Good Corporate Governance Mengesampingkan Hak-Hak Istimewa demi Kelangsungan Usaha. Jakarta: Prenada Media Group

Theacini, D.A.M dan Wisadha, I. G. S. (2014). Pengaruh Good Corporate Governance, Kualitas Laba dan Ukuran Perusahaan Pada Kinerja Perusahaan, E-Jurnal Akuntansi Universitas Udayana, Vol. 7, No.3 Hal: 733-746.

Torang, S. (2013). Organisasi dan Manajemen (Perilaku, Struktur, Budaya \& Perubahan Organisasi. Alfabeta. Bandung.

Wahidahwati. (2002). "Pengaruh Kepemilikan Manajerial dan Kepemilikan Institusional pada Kebijakan Hutang Perusahaan: Sebuah Perspektif Theory Agency", Jurnal Riset Akuntansi Indonesia, Vol. 5, No. 1, Ikatan Akuntan Indonesia-Kompartemen Akuntan Pendidik, Yogyakarta.

Widagdo, D.O.K. dan A. Chariri (2014). Pengaruh Good Corporate Governance Terhadap Kinerja Perusahaan. Diponegoro Journal of Accounting, Vol. 3, No. 3, Hal: 1-9

Zerban, A.M dan W.B. Din Ateia. (2016). Corporate Governance in the Banking Sector (Empirical Study on the Effect of Separating Chairman and Chief Executive Officer (CEO) Positions on Financial Performance). Accounting and Finance Research, Vol. 5, No. 3. 